\title{
Family and School in the Socioemotional Development in Childhood
}

\author{
Giovanna Wanderley Petrucci ${ }^{1}$ \\ Departamento de Fisiologia da Universidade Federal do Rio Grande do Norte, \\ Natal, RN, Brasil \\ Juliane Callegaro Borsa \\ Departamento de Psicologia da Pontifícia Universidade Católica do Rio de Janeiro, \\ Rio de Janeiro, RJ, Brasil \\ Sílvia Helena Koller \\ Departamento de Psicologia do Desenvolvimento e da Personalidade da Universidade \\ Federal do Rio Grande do Sul, Porto Alegre, RS, Brasil
}

\begin{abstract}
This study presents a non-systematic review of the literature on the effects that proximal processes experienced in the family and in school have on the socioemotional development during childhood. According to the bioecological model, these proximal processes are promoters of human development, which may facilitate the adaptation of individuals to the various contexts in which they are inserted. These processes include the relationships of children with parents and teachers, which make the individual's interaction with the environment possible. The family and the school also share the roles of education and socialization in childhood. Therefore, they should be investigated jointly, resulting in information that may contribute to the development of public policies for the overall development of children. The school, in particular, is considered a social institution responsible for the implementation of the rights of children and adolescents and for meeting their educational and socioemotional demands. The school environment can act as a protective factor for children at risk. Empirical studies that investigate proximal processes as protective factors in childhood can assist in the planning of interventions aimed at improving their quality in the family and school context, in order to bring about a healthy human development.
\end{abstract}

Keywords: Family, school, proximal processes, bioecological model, childhood.

\section{A Família e a Escola no Desenvolvimento Socioemocional na Infância}

\section{Resumo}

Este estudo apresenta uma revisão não sistemática da literatura acerca dos efeitos de processos proximais vivenciados na família e na escola sobre o desenvolvimento socioemocional na infância. De acordo com o modelo bioecológico, esses processos atuam como promotores do desenvolvimento humano, podendo facilitar a adaptação dos indivíduos aos diversos contextos em que estão inseridos. Dentre esses processos, destacam-se os relacionamentos da criança com os pais e com os professores, que pos-

Mailing address: Rua Ramiro Barcelos, 2600, sala 104, Santa Cecília, Porto Alegre, RS, Brasil 90035003. E-mail: giovannapetrucci@gmail.com,juliborsa@gmail.com e silvia.koller@gmail.com Financial support: Conselho Nacional de Desenvolvimento Científico e Tecnológico (CNPq). 
sibilitam a interação com o ambiente. A família e a escola compartilham ainda as funções de educação e de socialização na infância. Portanto, elas devem ser investigadas conjuntamente, resultando em informações que contribuam para o desenvolvimento de políticas públicas para o desenvolvimento global da criança. A escola, em particular, é considerada uma instituição responsável pela efetivação dos direitos de crianças e adolescentes e pelo atendimento às suas demandas educacionais e socioemocionais. $\mathrm{O}$ ambiente escolar pode atuar como fator de proteção para crianças que se encontram em situação de risco. Estudos empíricos que investiguem processos proximais como fatores de proteção na infância podem auxiliar no planejamento de intervenções que visem melhorar a sua qualidade no contexto familiar e escolar, tendo em vista o desenvolvimento humano saudável.

Palavras-chave: Família, escola, processos proximais, modelo bioecológico, infância.

\section{Familia y Escuela en el Desarrollo Socioemocional en la Infancia}

\section{Resumen}

Este estudio presenta una revisión no sistemática de la literatura sobre los efectos de los procesos proximales en la familia y en la escuela en el desarrollo socio-emocional en la infancia. De acuerdo con el modelo bioecológico, estos procesos proximales actúan como promotores del desarrollo humano y pueden facilitar la adaptación de los individuos a diversos contextos. Entre estos procesos, destacamos las relaciones del niño con los padres y los maestros, que permiten la interacción con el entorno. La familia y la escuela todavía comparten las funciones educativas y de socialización en la infancia. Por lo tanto, deben ser investigados juntos, lo que resulta en información que pueda contribuir al desarrollo de políticas públicas para el desarrollo general de los niños. La escuela es una institución encargada de la aplicación de los derechos de los niños y adolescentes y para satisfacer sus demandas educativas y socioemocionales. El entorno escolar puede actuar como un factor de protección para los niños que están en riesgo. Los estudios empíricos que investigan los procesos proximales como factores protectores en la infancia pueden ayudar en la planificación de las intervenciones para mejorar la calidad en la familia y la escuela para el desarrollo humano saludable.

Palabras clave: Familia, escuela, procesos proximales, modelo bioecológica, infancia.

The family and the school are fundamental contexts to human development, and may contribute to the promotion of socioemotional competences and to reduce internalizing and externalizing behavior problems (Barbosa, Santos, Rodrigues, Furtado, \& Brito, 2011; Campbell, Pungello, \& Miller-Johnson, 2002; O'Connor \& McCartney, 2006; Silver, Measelle, Armstrong, $\&$ Essex, 2005). It is possible to investigate separately the effects of each of these contexts on the development of children. However, due to the role of socialization and education in childhood that they share, they should be understood jointly (Oliveira \& Marinho-Araújo, 2010).

Systemic theoretical models have been widely used to explain human development from the effects of interaction people had with different environments (Lerner, 2006). One such example is the bioecological model, proposed by the psychologist Urie Bronfenbrenner, which has been useful to investigate proximal processes experienced by children in different contexts, as well as their consequences (Cecconello, De Antoni, \& Koller, 2003; Diniz \& Koller, 2010; Lisboa, 2005).

For the bioecological model, human development is a process of continuities and changes in the characteristics of people and groups which occurs throughout the life cycle and across generations (Bronfenbrenner, 2001). A central concept to this model are the proximal processes related to the everyday activities people have with other individuals, objects and symbols on their immediate contexts, which become progressively more complex over time. Some examples of proximal processes are games 
played by children, school learning activities, the relationships of children with their parents and teachers and playing sports.

Proximal processes are considered as development engines. Their strength and quality are influenced by characteristics of the person, the context and the time (Bronfenbrenner, 2001). In this sense, according to the bioecological model, the interaction of all these factors results in human development and may cause effects of competence or of dysfunction on the individual, requiring them to be jointly examined (Bronfenbrenner \& Morris, 2006). The effects of competence result in the acquisition and subsequent development of knowledge and intellectual, physical and socioemotional skills. On the other hand, the effects of dysfunction result in recurrent manifestations of difficulties in controlling their own behavior in various situations (Bronfenbrenner \& Morris, 2006).

Studies conducted in the United States, have shown that the proximal processes experienced in the family and at school can act as protective factors for students who are facing individual or social adversities (Baker, Grant, \& Morlock, 2008; Loukas, Roalson, \& Herrera, 2010; O'Connor \& McCartney, 2006; Whittaker, Harden, See, Meisch, \& Westbrook, 2011). Although scarce, this kind of studies can be of great social relevance also to developing countries, such as Brazil (Diniz, Piccolo, Paula Couto, Salles, \& Koller, 2013; Raffaelli, Koller, $\&$ Cerqueira-Santos, 2012), which have a large number of vulnerable children and adolescents due to high levels of social inequality or sociocultural characteristics (United Nations Children's Fund [UNICEF], 2012). In view of this reality that can maximize the risk factors for childhood development, a greater understanding of possible protective factors that are able to reduce the effects of these problems on the lives of individuals is required (Fonseca, Sena, Santos, Dias, \& Costa, 2013; Koller \& Lisboa, 2007; Poletto, Koller, \& Dell'Aglio, 2009). This understanding can encourage the development of interventions focused on family and school contexts aimed at the full development of Brazilian children.
Accordingly, this non-systematic literature review gathers studies which address proximal processes experienced in the family and school contexts. Initially, the role of the family as the principal development context is shown, especially the proximal processes that occur between children and their first caregivers. Then, the role of school as the second context of development is highlighted, emphasizing the proximal processes that occur between students and teachers. Finally, the role of the school is shown as a protective context for students who find themselves in conditions of individual or family vulnerability, which can promote socioemotional development in childhood.

\section{The Family as the First Development Context}

The family is the main context of human development, where children's first social interactions take place. That is where they start learning concepts, rules and cultural practices that underlie the processes of socialization of individuals (Bronfenbrenner, 2005/2011). For a number of theoretical models, interactions with the first caregivers in the family are especially responsible for socioemotional development in childhood. The personal attributes and the educational practices of these caregivers influence the quality of the relationship with the child, which, in turn, can affect the development of behaviors adapted or un-adapted in different environments (Rubin \& Burgess, 2002). For the bioecological model, particularly, the parents-child relationship is considered as a proximal process, which interacts with aspects of the context, of the person and of the time, resulting in different development outcomes (Bronfenbrenner, 2001).

Based on the bioecological model, Whittaker et al. (2011) investigated the effect of factors present in poor families living in the United States on the development of socioemotional competence in childhood. The results indicated that contextual risk variables (inadequacy of family resources and family conflict) influenced parental stress, which exerted a negative effect 
on children (Whittaker et al., 2011). In addition, maternal sensitivity acted as a mediator in the relationship between parental stress and the socioemotional functioning of children. From the results, it was concluded that the way parents responded to the needs of children can play an important role in protecting children against the effects of adverse family processes, such as parental stress. Although such risks have negatively influenced the socioemotional competences of children, high maternal sensitivity served as a protective factor, especially for those who living in greater poverty (Whittaker et al., 2011).

There are also other family factors related to socioemotional development (Bronfenbrenner, 1986). Research has shown, for example, the association between family environment and childhood characteristics, such as behavioral problems (Schultz \& Shaw, 2003), social skills performance (Valencia \& López, 2011) and the quality of mother-child communication (Laible, 2010). In one of their definitions, the family environment refers to the individuals' perception as to the quality of inter-family relationships. It can be evaluated through factors such as cohesion, support, conflict and hierarchy in interactions (Teodoro, Allgayer, \& Land, 2009). Cohesion refers to the emotional bond between family members. Support refers to the emotional and material support that some offer to others. Conflict refers to negative inter-family feelings that cause a confrontational, hostile and aggressive environment. Hierarchy refers to the differentiation of power and control in intergenerational relations (Teodoro et al., 2009).

In the study developed by Sbicigo and Dell'Aglio (2012), high levels of support and cohesion, and low levels of family conflict were considered as predictors of psychological adaptation in Brazilian adolescents. Those who perceived high family cohesion and support probably felt higher levels of acceptance and love from their families, which may have raised their levels of self-esteem and self-efficacy. The authors stressed that the perception of family environment is influenced by individual characteristics. In this sense, people in the same family may have different perceptions of the family environment, resulting in different levels of psychological adaptation (Sbicigo \& Dell'Aglio, 2012).

In addition to family environment, sociodemographic variables such as socioeconomic status, educational level of parents and parental conflict may also be associated with problematic or competent behaviors in childhood (Bandeira, Rocha, Freitas, Del Prette, \& Del Prette, 2006; Borsa \& Nunes, 2011; Borsa, Souza, \& Bandeira, 2011; Schultz \& Shaw, 2003). The studies of Borsa and Nunes (2011) and Borsa et al. (2011), conducted within the Brazilian context showed a higher frequency of behavior problems in elementary school children who studied in public schools, had low family income and whose parents had a low education level. For Borsa et al. (2011), it is necessary to give greater attention to the effects of sociodemographic variables on inter-family relationships and, consequently, on the development of individuals (Borsa et al., 2011).

In short, many research cases have identified the association between variables of family and competent or problematic behaviors in childhood (Bandeira et al., 2006; Borsa et al., 2011; Valencia \& López, 2011). However, Brazilian studies regarding the effects of interactions among the characteristics of the family, of the person and of the time for child development are scarce (De Antoni \& Koller, 2011; Koller $\&$ De Antoni, 2011). In addition, although the family microsystem has a fundamental role for individuals, as children grow up they become part of other contexts that provide them with new socioemotional and cognitive experiences which are essential for healthy development (Berry \& O'Connor, 2010; O'Connor \& McCartney, 2006).

\section{The Role of School in the Development of Children}

School is the second context where the majority of children attend regularly, representing a social living space where, primarily, 
interactions with peers and with teachers are built (Pianta, Nimetz, \& Bennet, 1997). After the child enters the school, teachers can become a source of emotional support and safety, contributing to students' adaptation to the new environment (O'Connor \& McCartney, 2006).

The presence of teachers is transient in the lives of students, rarely resulting in lasting interactions such as those with family members. However, due to their caregiver role throughout a school year, the teacher-student relationship is a proximal process that occurs in the school environment, and can act as a predictor in the development of competences and dysfunctions in children (Hamre \& Pianta, 2006; Maldonado-Carreño \& Votruba-Drzal, 2011; Pianta et al., 1997). As students grow, their interests change. However, the need for interactions with adults in the school context accompanies them until adolescence (Crosnoe, Johnson, \& Elder, 2004; Hamre \& Pianta, 2006).

Studies on the teacher-student relationship with children in U.S. elementary schools have demonstrated their relevance to the socioemotional development in childhood (Berry \& O'Connor, 2010; Maldonado-Carreño \& Votruba-Drzal, 2011; O'Connor \& McCartney, 2006). When positive, these relationships are associated with improvement in school performance and reduction in behavior problems (Maldonado-Carreño \& Votruba-Drzal, 2011), as well as the development of social skills (Berry \& O'Connor, 2010). Moreover, as the students progress in elementary school, the importance of these relationships for the development remains constant (Berry \& O'Connor, 2010; Maldonado-Carreño \& Votruba-Drzal, 2011).

These results are advancing towards identifying the relevance of the teacher-student relationship for the development of children from kindergarten through adolescence. For younger children, the positive relationship with teachers can make them feel safer to participate in school activities and interact with peers, because they know that, if they face any difficulties, they could rely on the support of the teachers. For children in more advanced years, a positive teacher-student relationship helps them maintain an interest in school and social activities, encouraging better school performance and a positive relationship with peers (Hamre \& Pianta, 2006).

There are still other important variables in the school context for the socioemotional development of students. The school environment, for example, refers to various aspects of life at school, from physical to social aspects, not limited to individual experiences of students, teachers or people in the community (Zullig, Koopman, Patton, \& Ubbes, 2010). According to Haynes, Emmons and Ben-Avie (1997), the school environment is related to the quality and consistency of personal interactions at school, which influence the cognitive, social and psychological development of students. For Cohen, McCabe, Michelli, and Pickeral (2009), the school environment refers not only to social interactions, but to the multiple aspects of school, such as standards, goals, values, quality of interpersonal relationships, teaching and learning practices and organizational structures of the school. These aspects are based on people's previous experiences and reflect the quality and characteristics of everyday school life.

Although there is no consensus about the dimensions that characterize the school environment, it is known that it is the result of multiple factors present in school, from individual to social factors. Analyzing these factors according to the bioecological model, some of them can be considered proximal processes, such as the quality of students' interpersonal relationships with peers or teachers; others may be considered as factors of school microsystem, such as standards and goals of the school or the educational model adopted by teachers; others, still, can be named as school mesosystem factors, such as parental involvement with teachers. The school environment, therefore, refers to multiple aspects of the school, and may influence, either directly or indirectly, the socioemotional development of students.

In this sense, U.S. studies show that the students' perception about the school environment is associated with different outcomes of 
behaviors at school, such as behavior problems (Wang \& Dishion, 2011), adaptation to school (Haynes et al., 1997; Zullig, Huebner, \& Patton, 2011) and social skills (Esposito, 1999). When positive, the school environment is able to promote the socioemotional development of students in general and especially of those who are vulnerable due to the presence of individual or family risks. A negative school environment, on the other hand, can act as a risk factor to the healthy development of the students (Hopson \& Lee, 2011; Loukas et al., 2010; Wang \& Dishion, 2011).

Also, the school context has other factors relevant to the socioemotional development in childhood, such as location, size and amount of material resources of the school, the number of students in the classroom, in addition to personal characteristics of the children and teachers. It is important for them to be evaluated together in order to achieve an understanding their effects (independent and interactive) have on individuals in different contexts. This information can contribute to the effectiveness of implementation of positive school practices focused on the promotion of healthy human development in different schools (Hamre \& Pianta, 2005; O'Connor, 2010).

\section{The School as a Protective Context for Socioemotional Development}

Given that family and school are important socialization contexts for children, studies have investigated the association between childhood behaviors and characteristics of family (Borsa \& Nunes, 2011; Valencia \& Lopes, 2011; Whittaker et al., 2011) or of school (Baker et al., 2008; Berry \& O'Connor, 2010; Maldonado-Carreño \& Votruba-Drzal, 2011; Picado \& Rose, 2009). However, little has been researched about the interaction of these two contexts and their implications for development and, specifically, about how school can act as a protective factor for students who are under individual or family risk factors (Hopson \& Lee, 2011; Loukas et al., 2010; O'Connor \& McCartney, 2006; Silver et al., 2005; Wang \& Dishion, 2011).
Children who develop in family environments that support their socioemotional needs tend to adapt more easily to new contexts, demonstrating high social competence and low levels of behavior problems (Campbell et al., 2002; Whittaker et al., 2011). On the other hand, children who develop in family environments whose relationships are conflicting and hostile, or whose social and material resources are scarce, may have difficulty in adapting to the demands of new environments. In these cases, especially, the variables of school, such as teacher-student relationship and a positive school environment can contribute to the healthy development of the individual. They can act as setoff factors for negative family relationships in so far as they provide children with opportunities to develop important skills for social adaptation in other contexts (Hopson \& Lee, 2011; O'Connor \& McCartney, 2006; Silver et al., 2005).

Several studies have investigated the role of teacher-student relationship as a moderator for children who are at risk due to individual or contextual characteristics (Baker et al., 2008; Hamre \& Pianta, 2005; Loukas et al., 2010; O'Connor \& McCartney, 2006; Silver et al., 2005). For example, O'Connor and McCartney (2006) examined the effect of maternal attachment (at 15, 24 and 36 months of age) and of the child's relationship with daycare caregivers (at 54 months) on the quality of the teacher-student relationship in the first school years. From the results, it was observed that the teacher-student relationship in school was directly influenced by the relationship of the child with the daycare caregivers and was indirectly influenced by the quality of maternal attachment. In this sense, the relationship of the child with daycare caregivers served as a mediator in the association between maternal attachment and quality of teacher-student relationship in school. In addition, high-quality relationship in daycare was regarded as an offset for children with insecure maternal attachment, contributing to their healthy development. The authors suggested that children with insecure maternal attachment could benefit from positive relationships with caregivers in preschool institutions. 
The study of Silver et al. (2005) assessed the unique and interactive effect of factors of child, family and school on the trajectory of externalizing behaviors in the classroom, on students from the beginning of elementary school. The following predicting variables were considered: previous externalizing behaviors of the child, parental educational practices and quality of teacher-student relationship. According to the results, the relationship with the teachers produced stronger effects than the relationships with parents on the trajectory of externalizing behaviors of students, and may maintain, increase or reduce them over the years. In addition, the affinity in the relationship with the teachers acted as a protective factor for children with a high level of behavioral problems early in the school trajectory (Silver et al., 2005). For these children, a closer relationship with teachers resulted in decreased behavioral problems over time, while less proximity resulted in an increase of these problems, there being no differences between the sexes of the students (Silver et al., 2005). The relationship with the teachers promoted a context of emotional support for children, contributing to their success in the transition to school.

Consistent with the attachment theory, positive relationships with adults outside the family context can act as protective factors for children with negative family relationships. This is because positive interactions with adults can contribute to the mental and emotional reorganization of dysfunctional relationship models of children. However, we need to explore through what mechanisms the relationships with teachers can protect individuals who find themselves in situations of risk (Sabol \& Pianta, 2012).

Other studies have examined the effects of the school environment as a moderator for children and adolescents in situations of individual or family vulnerability (Hopson \& Lee, 2011; Loukas et al., 2010; Wang \& Dishion, 2011). The study developed by Hopson and Lee (2011), for example, investigated the influence of the school environment in the association of poverty in the family with school grades and with adolescents' behavior problems. In this study, the school environment referred to the students' perception about factors such as school quality, feeling of connection with the school and relationships with the adults in the school. The results indicated that the perception of the school environment acted as a moderator only for students' behavior problems. All participants who reported a positive perception of school environment had a lower frequency of behavior problems, and such results were stronger for students from poorer families. In this sense, the study highlighted importance of a positive school environment to reduce possible losses arising from the low socioeconomic status of families (Hopson \& Lee, 2011).

The study of Loukas et al. (2010) included the goal of investigating the independent and interactive effect of the students' bond with the school and the quality of their inter-family relationships on the development of conduct problems in adolescence. The bond with the school contributed to reducing conduct problems over time. In addition, it reduced the effects of the low quality of inter-family relationships on conduct problems in boys and girls. For Loukas et al. (2010), adolescents who feel connected with a group, regardless of what it may be, are most likely to understand and meet social expectations, demonstrating a lower frequency of conduct problems when compared with their peers who are less connected socially.

Wang and Dishion (2011) investigated possible effects of school environment moderation on the association between deviant peer affiliation and behavior problems during the second cycle of elementary school. The school environment was assessed through four dimensions: academic support, student behavior management, social support of teachers and social support of peers. The hypothesis of moderation was confirmed for the behavioral management and social support of teachers dimensions. Students who perceived higher levels of behavioral management in school followed school standards more frequently and, consequently, were less involved with deviant peers. In addition, students who perceived 
greater social support of teachers presented a higher level of connection with the school, lower risk for emotional stress and higher frequency of socially accepted behaviors (Wang \& Dishion, 2011).

Positive school environment and positive teacher-student relationship can act as moderators for students who are in different conditions of risk, such as negative family relationships, socioeconomic difficulties in the family, high frequency of externalizing behaviors and association with deviant peers. The effect of interaction of these variables illustrates Bronfenbrenner's perspective that human development is the result of the interrelationship of different factors of the person, the context and time, including the proximal processes as engines of development (Bronfenbrenner \& Morris, 2006). The examples presented in this study emphasized the teacher-student relationship as a proximal process experienced by students. The school environment, due to its diversity of definitions, can be considered at times as a proximal process (for example, social support of teachers), and at other times as a factor of the context (for example, behavioral management in school). Still, it was observed that both variables acted as protective factors for different risks arising from family or individual vulnerabilities.

Although the studies reported have been conducted mainly in the United States, and their results impossible to be generalized to other cultures, they provide indications of the significance of family and school for socioemotional development in childhood. Each cultural context usually has its own school operation rules, containing provisions on class load, teachers' assignments, the school's physical structure, among others. In addition, each society has expectations regarding the role of the family in people's lives, expectations which are influenced by cultural and religious aspects of each locality. Therefore, we must stress the need for greater understanding about the unique and interactive influence multiple variables have on socioemotional development in different contexts.

\section{Final Considerations}

The purpose of this study was to discuss the importance of family and school for socioemotional development in childhood, based on empirical studies selected by means of a non-systematic review of the literature. It emphasized the relationship of children with parents and teachers, which, according to the bioecological model, are considered proximal processes that are fundamental to human development. It also addressed how the teacher-student relationship and the school environment can act as protective factors for students who are in conditions of individual or family vulnerability.

The family is one of the social institutions responsible for primary socialization of people (Bronfenbrenner, 2005/2011), highlighting some important factors for children, such as the quality of the relationship with the parents, the family atmosphere, the characteristics of individuals and the physical environment of the family, and the events that have occurred in people's lives or in society. However, families are also subject to the adverse conditions existing in the socioeconomic context in which they are inserted, such as high rates of unemployment, lack of basic sanitation, family disorganization, among others, which could harm child development (Fonseca et al., 2013). Given that, we highlight the role of school as one of the social institutions responsible for the implementation of the rights of children and adolescents, by meeting not just their school demands, but also their socioemotional demands (Faleiros \& Faleiros, 2008). Some school context factors that are important for development in childhood are the quality of teacher-student relationship, the school environment, peer relationships, school location, and the availability of material resources for school activities.

Considering that both family and school share the functions of education and socialization in childhood, it is important to investigate the individual and interactive effects of different factors within those contexts on the development of children. We highlight the central 
role of proximal processes, such as the child's relationships with parents and teachers, which are fundamental for the development of adapted or non-adapted behaviors, since they enable the child's interaction with the environment.

One of the limitations of this study is the absence of systematization in the literature review and the scarcity of national empirical studies that could support the information presented. However, it was demonstrated that the family and school factors need to be investigated jointly so as to be used in favor of adapted development and for public policies aimed at the promotion of the overall development of children. The intention is not to transfer the responsibility of families to schools or vice versa. However, when thinking about the function of socialization of children shared by families and schools, it is suggested that both should be prepared to act when necessary, especially when either of the two fails.

\section{References}

Baker, J. A., Grant, S., \& Morlock, L. (2008). The teacher-student relationship as a developmental context for children with internalizing or externalizing behavior problems. School Psychology Quarterly, 23, 3-15. doi:10.1037/10453830.23.1.3

Bandeira, M., Rocha, S. S., Freitas, L. C., Del Prette, Z. A. P., \& Del Prette, A. (2006). Habilidades sociais e variáveis sociodemográficas em estudantes do ensino fundamental. Psicologia em Estudo, 11, 541-549.

Barbosa, A. J. G., Santos, A. A. A., Rodrigues, M. C., Furtado, A. V., \& Brito, N. M. (2011). Agressividade na infância e contextos de desenvolvimento: Família e escola. Psico, 42, 228-235.

Berry, D., \& O’Connor, E. (2010). Behavioral risk, teacher-child relationships, and social skill development across middle childhood: A childby-environment analysis of change. Journal of Applied Developmental Psychology, 31, 1-14. doi:10.1016/j.appdev.2009.05.001

Borsa, J. C., \& Nunes, M. L. T. (2011). Prevalência de problemas de comportamento em uma amostra de crianças em idade escolar da cidade de Porto Alegre. Aletheia, 34, 32-46.
Borsa, J. C., Souza, D. S., \& Bandeira, D. R. (2011). Prevalência dos problemas de comportamento em uma amostra de crianças do Rio Grande do Sul. Psicologia: Teoria e Prática, 13, 15-29.

Bronfenbrenner, U. (1986). Ecology of the family as a context for human development: Research perspectives. Developmental Psychology, 22, 723742. doi:10.1037/0012-1649.22.6.723

Bronfenbrenner, U. (2001). The bioecological theory of human development. In N. J. Smelser \& P. B. Baltes (Eds.), International encyclopedia of the social and behavioral sciences (pp. 6963-6970). Oxford, UK: Elsevier.

Bronfenbrenner, U. (2011). Fortalecendo os sistemas da família. In U. Bronfenbrenner, Bioecologia do desenvolvimento humano: Tornando os seres humanos mais humanos (pp. 277-289). Porto Alegre, RS: Artmed. (Original work published 2005)

Bronfenbrenner, U., \& Morris, P. A. (2006). The bioecological model of human development. In W. Damon (Series Ed.) \& R. M. Lerner (Vol. Ed.), Handbook of child psychology (Vol. 1, $6^{\text {th }}$ ed., pp. 793-828). New York: John Wiley \& Sons.

Campbell, F. A., Pungello, E. P., \& Miller-Johnson, S. (2002). The development of perceived scholastic competence and global self-worth in African American adolescents from lowincome families: The roles of family factors, early educational intervention, and academic experience. Journal of Adolescent Research, 17, 277-302.

Cecconello, A. M., De Antoni, C., \& Koller, S. H. (2003). Práticas educativas, estilos parentais e abuso físico no contexto familiar. Psicologia em Estudo, 8, 45-54. doi:10.1590/S141373722003000300007

Cohen, J., McCabe, E. M., Michelli, N. M., \& Pickeral, T. (2009). School climate: Research, policy, practice, and teacher education. Teachers College Record, 111(1), 180-213. doi:10.1007/ s10464-015-9751-x

Crosnoe, R., Johnson, M. K., \& Elder, G. H. (2004). Intergenerational bonding in school: The behavioral and contextual correlates of student-teacher relationships. Sociology of Education, 77, 60-81. doi:10.1177/003804070407700103

De Antoni, C., \& Koller. S. H. (2011). A pesquisa ecológica sobre violência no microssistema familiar. In S. H. Koller (Ed.), Ecologia do desen- 
volvimento humano: Pesquisa e intervenção no Brasil (pp. 315-339). São Paulo, SP: Casa do Psicólogo.

Diniz, E., \& Koller, S. H. (2010). O afeto como um processo de desenvolvimento ecológico. Educar em Revista, 36, 65-76. doi:10.1590/S010440602010000100006

Diniz, E., Piccolo, L. R., Paula Couto, M. C., Salles, J. F., \& Koller, S. H. (2013). Influences of developmental contexts and gender differences on school performance of children and adolescents. Educational Psychology: An International Journal of Experimental Educational Psychology. Retrieved from http://www.tandfonline.com

Esposito, C. (1999). Learning in urban blight: School climate and its effect on the school performance of urban, minority, low-income children. School Psychology Review, 28, 365-377. doi:10.1007/ s10560-014-0343-7

Faleiros, V. P., \& Faleiros, E. S. (2008). Escola que protege: Enfrentando a violência contra crianças e adolescentes: Educação para todos. Brasília, DF: Ministério da Educação, Secretaria de Educação Continuada, Alfabetização e Diversidade.

Fonseca, F. F., Sena, R. K. R., Santos, R. L. A., Dias, O. V., \& Costa, S. M. (2013). As vulnerabilidades na infância e adolescência e as políticas públicas brasileiras de intervenção. Revista Paulista de Pediatria, 31, 258-264. doi:10.1590/ S0103-05822013000200019

Hamre, B. K., \& Pianta, R. C. (2005). Can instructional and emotional support in the first-grade classroom make a difference for children at risk of school failure? Child Development, 76, 949967. doi:10.1111/j.1467-8624.2005.00889.x

Hamre, B. K., \& Pianta, R. C. (2006). Student-teacher relationships. In G. G. Bear \& K. M. Minke (Eds.), Children's needs III: Development, prevention, and intervention (pp. 59-72). Washington, DC: National Association of School Psychologists.

Haynes, N., Emmons, C., \& Ben-Avie, M. (1997). School climate as a factor in student adjustment and achievement. Journal of Educational and Psychological Consultation, 83, 321-329. doi:10.1207/s1532768xjepc0803 4

Hopson, L. M., \& Lee, E. (2011). Mitigating the effect of family poverty on academic and behavioral outcomes: The role of school climate in middle and high school. Children and Youth Services Review, 33, 2221-2229. doi:10.1016/j. childyouth.2011.07.006

Koller, S. H., \& De Antoni, C. (2011). Violência intrafamiliar: Uma visão ecológica. In S. H. Koller (Ed.), Ecologia do desenvolvimento humano: Pesquisa e intervenção no Brasil (pp. 297-314). São Paulo, SP: Casa do Psicólogo.

Koller, S. H., \& Lisboa, C. (2007). Brazilian approaches to understanding and building resilience in at-risk populations. Child and Adolescent Psychiatric Clinics of North America, 16, 341-356. doi:10.1016/j.chc.2006.12.002

Laible, D. (2010). Does it matter if preschool children and mothers discuss positive vs. negative events during reminiscing? Links with motherreported attachment, family emotional climate, and socioemotional development. Social Development, 20, 394-411. doi:10.1111/j.14679507.2010.00584.x

Lerner, R. M. (2006). Developmental science, developmental systems, and contemporary theories of human development. In W. Damon (Series Ed.) \& R. M. Lerner (Vol. Ed.), Handbook of child psychology (Vol. 1, $6^{\text {th }}$ ed., pp. 1-17). New York: John Wiley \& Sons.

Lisboa, C. S. M. (2005). Comportamento agressivo, vitimização e relações de amizade de crianças em idade escolar: Fatores de risco e proteção (Doctoral dissertation, Programa de Pós-Graduação em Psicologia, Universidade Federal do Rio Grande do Sul, Porto Alegre, RS, Brazil).

Loukas, A., Roalson, A. L., \& Herrera, D. E (2010). School connectedness buffers the effects of negative family relations and poor effortful control on early adolescent conduct problems. Journal of Research on Adolescence, 20, 13-22. doi:10.1111/j.1532-7795.2009.00632.x

Maldonado-Carreño, C., \& Votruba-Drzal, E. (2011). Teacher-child relationships and the development of academic and behavioral skills during elementary school: A within- and betweenchild analysis. Child Development, 82, 601-616. doi:10.1111/j.1467-8624.2010.01533.x

O'Connor, E. (2010). Teacher-child relationships as dynamic systems. Journal of School Psychology, 48, 187-218. doi:10.1016/j.jsp.2010.01.001

O’Connor, E., \& McCartney, K. (2006). Testing associations between young children's relationships with mothers and teachers. Journal of Educatio- 
nal Psychology, 98, 87-98. doi:10.1037/00220663.98.1.87

Oliveira, C. B. E., \& Marinho-Araújo, C. M. (2010). A relação família-escola: Intersecções e desafios. Estudos de Psicologia (Campinas), 27(1), 99108. doi:10.1590/S0103-166X2010000100012

Pianta, R. C., Nimetz, S. L., \& Bennet, E. (1997). Mother-child relationships, teacher-child relationships, and school outcomes in preschool and kindergarten. Early Childhood Research Quarterly, 12, 263-280. doi:10.1016/S08852006(97)90003-X

Picado, J. R., \& Rose, T. M. S. (2009). Acompanhamento de pré-escolares agressivos: Adaptação na escola e relação professor-aluno. Psicologia Ciência e Profissão, 29, 132-145. doi:10.1590/ S1414-98932009000100011

Poletto, M., Koller, S. H., \& Dell'Aglio, D. D. (2009). Eventos estressores em crianças e adolescentes em situação de vulnerabilidade social de Porto Alegre. Ciência \& Saúde Coletiva, 14, 455-466. doi:10.1590/S1413-81232009000200014

Raffaelli, M., Koller, S. H., \& Cerqueira-Santos, E. (2012). Protective factors moderate between risk exposure and problem behaviour among low income Brazilian adolescents. British Journal of Educational Psychology, Monograph Series II, 9, 74-92.

Rubin, K. H., \& Burgess, K. (2002). Parents of aggressive and withdrawn children. In $\mathrm{M}$. Bornstein (Ed.), Handbook of parenting (Vol. 1, pp. 383-418). Hillsdale, NJ: Lawrence Erlbaum.

Sabol, T. J., \& Pianta, R. C. (2012). Recent trends on teacher-student relationship. Attachment \& Human Development, 14, 213-231. doi:10.1080/ 14616734.2012 .672262

Sbicigo, J. B., \& Dell'Aglio, D. D. (2012). Family environment and psychological adaptation in adolescents. Psicologia: Reflexão e Crítica, 25, 615622. doi:10.1590/S0102-79722012000300022

Schultz, D., \& S. Shaw, D. S. (2003). Boys' maladaptive social information processing, family emotional climate, and pathways to early conduct problems. Social Development, 12, 440-460. doi:10.1111/1467-9507.00242

Silver, R. B., Measelle, J. R., Armstrong, J. M., \& Essex, M. J. (2005). Trajectories of classroom externalizing behavior: Contributions of child characteristics, family characteristics, and the teacher-child relationship during the school tran- sition. Journal of School Psychology, 43, 39-60. doi:10.1016/j.jsp.2004.11.003

Teodoro, M. L. M., Allgayer, M., \& Land, B. (2009). Desenvolvimento e validade fatorial do Inventário do Clima Familiar (ICF) para adolescentes. Psicologia: Teoria e Prática, 11(3), 27-39.

United Nations Children's Fund. (2012). Situação mundial da infância 2012: Crianças em um mundo urbano. Retrieved from http://www.unicef.org/sowc2012

Valencia, L. I. V., \& López, G. C. H. (2011). Relaciones entre el clima social familiar y el desempeño en habilidades sociales en niños y niñas entre dos y tres años de edad. Acta Colombiana de Psicología, 14(1), 19-30.

Wang, M.-T., \& Dishion, T. J. (2011). The trajectories of adolescents' perceptions of school climate, deviant peer affiliation, and behavioral problems during the middle school years. Journal of Research on Adolescence, 22, 40-53. doi:10.1111/j.1532-7795.2011.00763.x

Whittaker, J. E. V., Harden, B. J., See, H. M., Meisch, A. D., \& Westbrook, T. R. (2011). Family risks and protective factors: Pathways to Early Head Start toddlers' social-emotional functioning. Early Childhood Research Quarterly, 26, 74-86. doi:10.1016/j.ecresq.2010.04.007

Zullig, K. J., Huebner, E. S., \& Patton, J. M. (2011). Relationships among school climate domains and school satisfaction. Psychology in the Schools, 48, 133-145. doi:10.1002/pits.20532

Zullig, K. J., Koopman, T. M., Patton, J. M., \& Ubbes, V. A. (2010). School climate: Historical review, instrument development, and school assessment. Journal of Psychoeducational Assessment, 28, 139-152. doi:10.1177/0734282909344205 